\title{
Correlations among Egg Production Traits in IWD and IWF Strains of White Leghorn
}

\author{
B. Sridevi ${ }^{1}$, S.T. Viroji Rao ${ }^{2}$, M. Gnana Prakash ${ }^{2}$, V. Ravinder Reddy ${ }^{3}$ and D. Krishna ${ }^{4}$ \\ ${ }^{1}$ Department of Animal Genetics and Breeding, College of Veterinary Science, Rajendranagar, PVNR Telangana Veterinary \\ University, Hyderabad, Telangana, INDIA \\ ${ }^{2}$ Department of Animal Genetics and Breeding, PVNR Telangana Veterinary University, Hyderabad, Telangana, INDIA \\ ${ }^{3}$ Department of Poultry Science, PVNR Telangana Veterinary University, Hyderabad, Telangana, INDIA \\ ${ }^{4}$ Department of Poultry Science, College of Veterinary Science, Korutla, Telangana, INDIA \\ *Corresponding author: B Sridevi; E-mail: sridevivet@gmail.com
}

Received: 3 May, 2021

Revised: 27 June, 2021

Accepted: 23 July, 2021

\begin{abstract}
Correlations are a measure of genetic factors shared between two traits. When two traits are highly genetically correlated, the genes that contribute to the traits are usually co-inherited. They contribute to understanding the development and pathways of traits, population-level gene flow and the co-occurrences of traits. They also play an important role in evolutionary biology. In the present investigation it was found that the genetic and environmental correlations of age at first egg with body weight were negative in IWD and positive in IWF strains. The genetic and environmental correlations of body weight with egg weight and egg production were positive in IWD and negative in IWF strain. The genetic and environmental correlations of egg weight at 40 weeks with EP40 and EP64 weeks were found negative. The genetic and environmental correlations of egg production upto 40 weeks with EP64 weeks were positive in magnitude in both the strains.

\section{HIGHLIGHTS}

(0 Genetic selection played a major role in improvement in production efficiency of poultry.

(0 The genetic improvement in White Leghorn is paving the way for exploiting the production potential of this breed.

( The high positive genetic correlation in the present study could be due to the pleotrophic genes affecting egg weight at various ages.
\end{abstract}

Keywords: Correlations, IWD, IWF, White leghorn

Poultry production is an important sector contributing to a high proportion of animal protein for human needs through meat and eggs. Genetic variation is the base for any future breeding strategies in all farm animal species and therefore genetic diversity within a species needs to be conserved. Genetic selection played a major role in improvement in production efficiency of poultry and brought about 85 to 90 percent of the changes that occurred in broiler growth rate over 50 years (Sharma and Chatterjee, 2006). The genetic improvement in White Leghorn is paving the way for exploiting the production potential of this breed.

The analysis of the genetic parameters viz. heritability and correlation between the economic traits is necessary for achieving genetic improvement through correlated response by selection. The estimates of genetic and phenotypic parameters of each generation should be studied for desired improvement in economic traits. Therefore, the present study was undertaken to elucidate the interrelationships that exist among the various

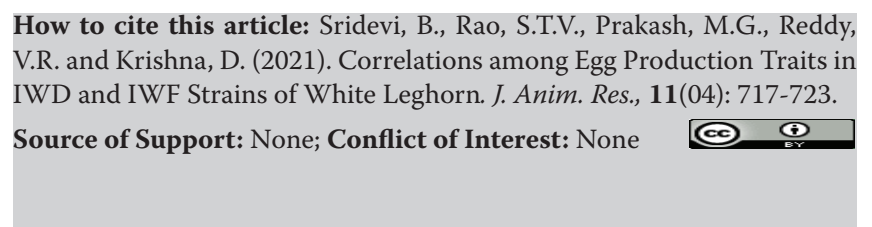


productive and reproductive traits of two strains of white leghorn. Information regarding correlation coefficient estimates is very useful in animal breeding as a means to predict potential response to, or progress from, selection. Since production traits are interrelated, considerations of such relationships are very relevant to selection for improvement.

\section{MATERIALS AND METHODS}

The present investigation was carried out on two strains of White Leghorns viz., IWD, IWF maintained at AICRP on poultry, Hyderabad.

The two strains were under selection for high egg production based on (EP40) Osborne index since 1971. The selection for the last 9 generations was based on EP64. The data on age at first egg (AFE), body weight at 16,40 and 64 weeks, egg weight at 28 and 40 weeks of age and egg production at 40 and 64 weeks of age were recorded. Erratic data from some progeny was omitted. In each generation 50 sires and 300 dams were selected. The data were corrected for significant effect of hatch by least squares method and further analysis was done on hatch corrected data.

\section{RESULTS AND DISCUSSION}

The genetic, and environmental correlations among the economic traits studied in nine generations are presented in table 1 and 2.

\section{Age at first egg with other traits}

The genetic correlation between AFE and body weight at 16 week is negative (Table 1) with moderate to high magnitude in both the strains. Environmental correlations were also showed negative sign in both the strains.

AFE showed negative genetic association with body weight 40 and 64 week in IWD however in IWF (Table 2) it was positive. Environmental correlation among above traits was negative in both strains.

The contrasting findings of genetic correlations of AFE with BW40 and BW64 were negative in IWD and positive in IWF. These findings were in accordance with the reports of Poggenpoel et al. (1996) which showed positive genetic correlations in White Leghorn strain, whereas the estimates from the strain of White Leghorn reported by Narwal et al. (2005) were negative in direction. Churchil et al. (2019) also observed estimates of correlations in opposite directions in two longterm selected strains of White Leghorn. Both genetic as well as environmental correlations among AFE and egg weight at 28, 40 and 64 weeks were negative in both the strains.

The genetic correlation estimates between AFE and egg production at 40 and 64 weeks were negative in both the strains indicating that birds which mature early produce more eggs because they will have more functional days as compared to late maturing birds. The environmental correlation was also negative and varied in magnitude from low to medium.

\section{Growth traits with other traits}

Body weights at different ages (16 weeks, BW 40 and BW $64)$ in both strains correlated positively genetically and environmentally.

Body weight at 16 weeks showed positive correlation with EW 28 weeks in IWD and negative in IWF strain whereas environmental correlations were positive in both the strains.

A positive genetic correlation was found between Body weight of 16 week with EW 40 and EW64 IWD strain but negative in IWF. Environmental correlation was found positive in both the strains. It indicates that birds which gain more weight at 16 weeks age produce eggs of more weight.

Both genetically and environmentally the body weight at 16 weeks correlated positively with EP 40 weeks both IWD and IWF but it showed negative correlation with EP 64 weeks in both strains. Environmental correlations were positive in IWD and IWF strains. BW 40 and BW 64 weeks correlated positively and high in magnitude in both IWD and IWF strains. In both strains BW 40 positively correlated in both aspects genetic as well as environmentally with EW 28, EW 40 and EW 64.

The genetic correlation and environmental correlations of body weight at 40 weeks with EP40 weeks was negative in IWD and IWF strains, and environmental correlations were also negative.

BW40 and EP64 weeks showed negative genetic 
Table 1: Estimates of genetic and environmental correlations of traits in IWD strain

\begin{tabular}{|c|c|c|c|c|c|c|c|c|c|}
\hline & AFE & BW16 & BW40 & BW64 & EW28 & EW40 & EW64 & EP40 & EP64 \\
\hline \multirow[t]{2}{*}{ AFE } & & $-0.51 /-0.15$ & $-0.43 /-0.02$ & $-0.41 /-0.01$ & $-0.49 /-0.04$ & $-1.19 /-0.02$ & $* * * * /-0.05$ & $-1.49 / 0.004$ & $-1.07 /-0.016$ \\
\hline & & $\begin{array}{l}(-0.53 \text { to } \\
0.78)\end{array}$ & $\begin{array}{l}(-0.86 \text { to } \\
0.65)\end{array}$ & $\begin{array}{l}(-0.45 \text { to } \\
0.21)\end{array}$ & $\begin{array}{l}(-0.54 \text { to } \\
0.27)\end{array}$ & $(-0.63$ to 0.31$)$ & $(-0.53$ to 0.43$)$ & (-1 to 0.24$)$ & (-1 to 0.74$)$ \\
\hline \multirow[t]{2}{*}{ BW16 } & $-0.22 / 0.08$ & & $0.49 / 0.02$ & $0.77 / 0.03$ & $0.40 / 0.003$ & $0.18 / 0.06$ & $* * * * / 0.08$ & $0.24 / 0.08$ & $0.13 / 0.07$ \\
\hline & $\begin{array}{l}(-0.23 \text { to } \\
0.08)\end{array}$ & & (0.49 to 1$)$ & (0.77 to 1$)$ & $\begin{array}{l}(0.03 \text { to } \\
0.78)\end{array}$ & $(0.29$ to 0.78$)$ & $(-0.03$ to 0.69$)$ & $(-0.38$ to 0.49$)$ & $\begin{array}{l}(-0.52 \text { to } \\
0.26)\end{array}$ \\
\hline \multirow[t]{2}{*}{ Bw40 } & $-0.03 / 0.06$ & $0.09 / 0.70$ & & $1 / 0.73$ & $0.43 /-0.03$ & $-0.06 /-0.03$ & $* * * * /-0.03$ & $-0.01 /-0.10$ & $-0.20 /-0.17$ \\
\hline & $\begin{array}{l}(-0.30 \text { to } \\
0.06)\end{array}$ & $\begin{array}{l}(0.87 \text { to } \\
0.06)\end{array}$ & & (0.73 to 1$)$ & $\begin{array}{l}(0.12 \text { to } \\
0.95)\end{array}$ & $(-0.06$ to 0.85$)$ & (0.92 to 0.14$)$ & (-1 to 0.11$)$ & $\begin{array}{l}(-0.91 \text { to } \\
0.09)\end{array}$ \\
\hline \multirow[t]{2}{*}{ Bw64 } & $-0.03 /-0.06$ & $0.09 / 0.25$ & $0.77 / 0.28$ & & $0.69 /-0.08$ & $-0.33 /-0.06$ & $* * * * / 0.01$ & $0.09 /-0.11$ & $0.01 /-0.22$ \\
\hline & $\begin{array}{l}(-0.06 \text { to } \\
0.07)\end{array}$ & $\begin{array}{l}(0.00 \text { to } \\
0.56)\end{array}$ & $\begin{array}{l}(0.01 \text { to } \\
0.77)\end{array}$ & & $\begin{array}{l}(-0.46 \text { to } \\
0.52)\end{array}$ & $\begin{array}{l}(-0.33 \text { to } \\
-0.53)\end{array}$ & ( 0.55 to 0.00 & (1 to -0.44$)$ & $(-0.10$ to 1$)$ \\
\hline \multirow[t]{2}{*}{ EW28 } & $0.05 /-0.01$ & $0.04 / 0.13$ & $0.01 / 0.14$ & $0.03 / 0.10$ & & $1 / 0.40$ & $* * * * / 0.08$ & $0.09 /-0.02$ & $0.06 /-0.05$ \\
\hline & $\begin{array}{l}(-0.05 \text { to } \\
0.13)\end{array}$ & $\begin{array}{l}(0.04 \text { to } \\
0.13)\end{array}$ & $\begin{array}{l}(-0.01 \text { to } \\
0.16)\end{array}$ & $\begin{array}{l}(-0.03 \text { to } \\
0.12)\end{array}$ & & (1 to 0.87 ) & (1 to 0.81 ) & $(-0.53$ to 0.09$)$ & $\begin{array}{l}(0.06 \text { to } \\
* * * *\end{array}$ \\
\hline \multirow[t]{2}{*}{ EW40 } & $-0.05 / 0.003$ & $0.06 / 0.13$ & $-0.03 / 0.15$ & $-0.04 / 0.09$ & $0.46 / 0.23$ & & $* * * * /-0.14$ & $0.27 / 0.05$ & $-0.08 / 0.06$ \\
\hline & $\begin{array}{l}(-0.05 \text { to } \\
0.07)\end{array}$ & $\begin{array}{l}(0.03 \text { to } \\
0.13)\end{array}$ & $\begin{array}{l}(0.03 \text { to } \\
0.23)\end{array}$ & -0.84 to 0.94 & $\begin{array}{l}(0.252 \text { to } \\
0.69)\end{array}$ & & ( 0.84 to 1 & $(-0.56$ to 0.27$)$ & $\begin{array}{l}(-0.36 \text { to } \\
0.14\end{array}$ \\
\hline \multirow[t]{2}{*}{ EW64 } & $0.01 /-0.03$ & $0.04 / 0.04$ & $0.01 / 0.08$ & $0.03 / 0.00$ & $0.04 / 0.12$ & $-0.16 / 0.69$ & & $* * * * * / 0.02$ & $* * * * * /-0.03$ \\
\hline & $\begin{array}{l}(-0.01 \text { to } \\
0.07)\end{array}$ & (0.02 to 0.1$)$ & 0.01 to 0.12 & $\begin{array}{l}(0.00 \text { to } \\
0.15)\end{array}$ & $\begin{array}{l}(0.042 \text { to } \\
0.59)\end{array}$ & $(-0.16$ to 0.69$)$ & & $(-0.84$ to 0.20$)$ & $\begin{array}{l}(-0.82 \text { to } \\
0.30)\end{array}$ \\
\hline \multirow[t]{2}{*}{ EP40 } & $-0.06 / 0.02$ & $0.09 / 0.32$ & $-0.10 / 0.27$ & $-0.12 / 0.01$ & $-0.01 / 0.01$ & $0.06 /-0.07$ & $-0.02 /-0.08$ & & $1 / 0.69$ \\
\hline & $\begin{array}{l}(-0.51 \text { to } \\
0.02)\end{array}$ & $\begin{array}{l}(-0.04 \text { to } \\
0.34)\end{array}$ & -0.10 to 0.27 & $\begin{array}{l}(-0.12 \text { to } \\
0.09)\end{array}$ & $\begin{array}{l}(-0.17 \text { to } \\
0.01)\end{array}$ & $(-0.24$ to 0.06$)$ & $\begin{array}{l}(-0.15 \text { to } \\
-0.01)\end{array}$ & & ( 0.14 to 1 \\
\hline \multirow[t]{2}{*}{ EP64 } & $-0.06 /-0.09$ & $0.08 / 0.07$ & $-0.16 /-0.02$ & $-0.23 /-0.01$ & $-0.04 / 0.03$ & $0.06 / 0.03$ & $-0.07 / 0.01$ & $0.70 / 0.0$ & \\
\hline & $\begin{array}{l}(-0.33 \text { to } \\
0.03)\end{array}$ & $\begin{array}{l}(-0.02 \text { to } \\
0.19\end{array}$ & $\begin{array}{l}-0.16 \text { to } \\
0.09)\end{array}$ & $\begin{array}{l}(0.23 \text { to } \\
0.06)\end{array}$ & $\begin{array}{l}(-0.14 \text { to } \\
0.03)\end{array}$ & $(-0.20$ to 0.06$)$ & $(-0.23$ to 0.01$)$ & $\begin{array}{l}5 \\
(0.05 \text { to } 0.80)\end{array}$ & \\
\hline
\end{tabular}

First line indicate $\mathrm{S} 1 / \mathrm{S} 9 ; * * * * *$ not estimable; Second line indicate range of S1 to S9 in which majority of values fit in.

correlations in IWD and IWF where as environmental correlations were positive. The result suggested that birds which were heavy 40 weeks age produce fewer eggs as the feed consumed may more diverted towards body mass than egg mass.

The genetic correlation and environmental correlations of body weight at 64 weeks with EW28 weeks were positive in IWD and IWF strains. Weight at 64 weeks correlated with EW 40 weeks was negative in IWD strain and positive in IWF and environmental correlations are negative in IWD and positive in IWF.
The genetic correlation and environmental correlations of body weight at 64 weeks with EW64 weeks was positive in both strains. However body weight at 64 weeks genetically correlated with EP40, EP64 in both strains whereas environmental correlations were negative among them.

\section{Egg weight with other traits}

The genetic and environmental correlations of Egg weight at 28 weeks with EW40, EW64 were positive and high in 
Table 2: Estimates of genetic and environmental correlations in IWF strain

\begin{tabular}{|c|c|c|c|c|c|c|c|c|c|}
\hline & AFE & BW16 & BW40 & BW64 & EW28 & EW40 & EW64 & EP40 & EP64 \\
\hline \multirow[t]{2}{*}{ AFE } & & $-1.41 /-1.73$ & $* * * * * / * * *$ & $-0.82 / * * *$ & $-1.92 / 0.64$ & $-1.00 / 0.90$ & $1 / 1$ & $-0.61 /-1$ & $-0.87 / * * *$ \\
\hline & & $\begin{array}{l}(-1.00 \text { to } \\
0.08)\end{array}$ & -0.13 to 0.58$)$ & $(-0.82$ to 1$)$ & -1 to 0.64 & -1.00 to 0.90 & -1.00 to 0.61 & $(-1$ to 0.36$)$ & $\begin{array}{l}(-1.00 \text { to } \\
0.18)\end{array}$ \\
\hline \multirow[t]{2}{*}{ BW16 } & $0.22 /-0.22$ & & $* * * / * * *$ & $0.8 / * * * *$ & $0.21 / 0.58$ & $-0.88 / 0.11$ & $-0.86 / 0.4$ & $-0.50 /-0.01$ & $0.89 / * * *$ \\
\hline & -0.43 to 0.22 & & 0.33 to 1 & ( 0.46 to 1 & $\begin{array}{l}-1.00 \text { to } \\
0.55\end{array}$ & -0.88 to 0.55 & -0.86 to 0.67 & $(-0.50$ to 0.52$)$ & $\begin{array}{l}(-0.89 \text { to } \\
0.83)\end{array}$ \\
\hline \multirow[t]{2}{*}{ BW40 } & $0.14 /-0.05$ & $0.43 / 0.15$ & & $* * * / 1$ & $* * * / * * *$ & $* * * * / * * * *$ & $* * * * / * * *$ & $* * * * / * * *$ & $* * * * / * * * *$ \\
\hline & -0.05 to 0.14 & 0.00 to 0.49 & & $(-0.94$ to 1$)$ & 0.14 to 0.52 & 0.19 to 0.73 & -0.04 to 0.67 & -0.35 to 0.10 & -0.43 to 0.17 \\
\hline \multirow[t]{2}{*}{ BW64 } & $0.17 /-0.13$ & $0.07 / 0.02$ & $0.09 / 0.27$ & & $0.17 / * * *$ & $-0.80 / * * *$ & $-0.32 / * * *$ & $-0.01 / * * * *$ & $* * * /-0.69$ \\
\hline & -0.13 to 0.17 & $\begin{array}{l}-0.03 \text { to } \\
0.39\end{array}$ & -0.08 to 0.73 & & $\begin{array}{l}-0.30 \text { to } \\
0.91\end{array}$ & -0.84 to 0.94 & -0.63 to 0.72 & $(-0.77$ to 0.08$)$ & $\begin{array}{l}(-0.87 \text { to } \\
0.16)\end{array}$ \\
\hline \multirow[t]{2}{*}{ EW28 } & $0.25 / 0.00$ & $0.14 / 0.00$ & $0.07 / 0.12$ & $0.11 / 0.06$ & & $-0.05 / 0.99$ & $0.41 / 0.69$ & $-0.16-0.39$ & $-0.63 / * * *$ \\
\hline & $\begin{array}{l}(-0.06 \text { to } \\
0.25\end{array}$ & $\begin{array}{l}-0.01 \text { to } \\
0.14\end{array}$ & -0.03 to 0.25 & -0.02 to 0.18 & & 0.91 to 1 & -0.71 to 1 & -0.58 to 0.16 & -0.63 to 0.28 \\
\hline \multirow[t]{2}{*}{ EW40 } & $0.25 /-0.03$ & $0.14 / 0.05$ & $0.07 / 0.06$ & $0.12 /-0.01$ & $0.73 / 0.19$ & & $-0.78 / 0.5$ & $-0.46 /-0.76$ & $-0.34 / * * *$ \\
\hline & -0.08 to 0.25 & $\begin{array}{l}-0.01 \text { to } \\
0.14\end{array}$ & -0.05 to 0.30 & -0.03 to 0.36 & 0.03 to 0.73 & & -0.78 to 1 & -0.60 to 0.21 & -0.61 to 0.39$)$ \\
\hline \multirow[t]{2}{*}{ EW64 } & $0.22 /-0.01$ & $0.16 / 0.00$ & $0.10 / 0.11$ & $0.16 /-0.03$ & $0.56 / 0.10$ & $0.62 / 0.07$ & & $0.29 / 0.21$ & $-0.01 / * * *$ \\
\hline & -0.07 to 0.22 & $\begin{array}{l}-0.02 \text { to } \\
0.17\end{array}$ & -0.05 to 0.22 & -0.09 to 0.17 & $\begin{array}{l}-0.07 \text { to } \\
0.56\end{array}$ & -0.11 to 0.75 & & -0.58 to 0.29 & -0.49 to 0.36 \\
\hline \multirow[t]{2}{*}{ EP40 } & $0.10 /-0.02$ & $0.06 / 0.05$ & $0.05 / 0.02$ & $0.08 /-0.04$ & $-0.06 / 0.00$ & $-0.1 /-0.1$ & $-0.05 /-0.07$ & & $-1 / * * * *$ \\
\hline & -0.70 to 0.22 & $\begin{array}{l}-0.07 \text { to } \\
0.35\end{array}$ & -0.05 to 0.10 & -0.11 to 0.09 & $\begin{array}{l}-0.22 \text { to } \\
0.00\end{array}$ & -0.25 to 0.10 & -0.18 to 0.18 & & $(-0.72$ to 1$)$ \\
\hline \multirow[t]{2}{*}{ EP64 } & $0.15 /-0.01$ & $0.12 /-0.01$ & $0.07 /-0.02$ & $0.10 /-0.09$ & $0.02 /-0.01$ & $-0.04 /-0.09$ & $-0.00 /-0.15$ & $0.78 / 0.69$ & \\
\hline & -0.27 to 0.10 & $\begin{array}{l}-0.03 \text { to } \\
0.27\end{array}$ & -0.05 to 0.13 & -0.11 to 0.12 & $\begin{array}{l}-0.14 \text { to } \\
0.02\end{array}$ & -0.26 to 0.16 & -0.20 to 0.40 & 0.09 to 0.81 & \\
\hline
\end{tabular}

First line indicate S1/S9; Second line indicate range of S1 to S9 in which majority of values fit in; ***** Not estimatable.

magnitude whereas Egg weight 28 correlated negatively with EP40.

The genetic and environmental correlations of Egg weight at 28 weeks with EP64 were not calculated in IWD strain and negative in IWF strain and environmental correlations are positive in both the strains. The genetic correlation and environmental correlations of Egg weight at 40 weeks with EW64 weeks was positive and high in magnitude.

\section{Egg weight vs Egg production}

The genetic and environmental correlations of EW 40 with EP 40 and EP 64 weeks were negative. Both the correlations among EW 64 and EP 64 weeks were negative indicating heavy layers show low egg weight.

\section{Egg production with other traits}

The genetic and environmental correlation of EP 40 weeks with EP 64 weeks was positive and high in magnitude in both the strains. The correlation estimates enable the breeder to predict the direction and magnitude of change in the dependent trait as a correlated response to direct selection for the principal trait.

The estimates based on the sire component of variance may not be reliable as they are usually based on lesser 
degrees of freedom. Similarly genetic correlations from dam component are inflated due to covariances of dominant deviations and maternal effects with large standard errors. Therefore, estimates obtained from sire + dam component would be more meaningful than estimates derived either from the sire or dam components alone and so are considered in the present discussion.

\section{Age at first egg $x$ growth trait}

The AFE associated in negative direction with 16 and 40 weeks body weight in both the strains under study were in accordance with the reports of Chatterjee et al. (2008a); Veeramani et al. (2008); Anees et al. (2010); Quadri et al. (2013). While the same trait showed correlation in both directions with 64 weeks body weight across generations. The environmental correlations between these traits in all the generations were negative and low to moderate in magnitude. The environmental correlation with body weights at 16, 40, and 64 weeks varied among the strains but the correlation was consistently negative, Chatterjee et al. (2008a); Jayalaxmi (2008), Veeramani et al. (2008) reported similar findings.

In the present investigation, AFE was negatively correlated with 28, 40 and 64 week, egg weight in two strains which was in agreement with the findings of Chatterjee et al. (2008a); Jayalaxmi (2008); Vasu et al. (2004a); Sreenivas et al. (2012). These negative genetic correlations indicated that the selection for earlier AFE will reduce egg weight at this age. Selection for high egg weight delays sexual maturity.

The environmental correlation of AFE with egg weight at various ages was not consistent and varied among the strains. The correlations were low to moderate in magnitude and negative in direction. Similar observations were made by Jayalaxmi (2008) indicating that birds maturing later due to environmental factors produce larger eggs when compared to birds that mature earlier.

The genetic correlation of AFE with EP40 weeks age was negative which is similar to the reports of Sharma and Krishna (1998); Sharma et al. (1999); Singh et al. (2000); Singh et al. (2001); Chatterjee et al. (2002); Singh et al. (2002); Rahman et al. (2003); Sethi et al. (2003); Kumar et al. (2004); Chatterjee et al. (2008a) and Jayalaxmi (2008). This indicates that any attempt to increase the egg production would favour early maturity and age at first egg. The negative genetic correlation of AFE with EP64 found in the study was in accordance to the reports of Kumar et al. (2004); Vasu et al. (2004a) and Jayalaxmi (2008). The environmental correlations also negative which was similar to findings of Chatterjee et al. (2008a) and Jayalaxmi (2008). This could be because birds maturing earlier will have longer production period and hence lay more number of eggs during production period.

\section{Growth Traits}

The genetic correlations were positive and high in magnitude among body weights 16, 40, 64 weeks. As most of the genes influencing initial bodyweight also influence body weight at subsequent stages. Similar findings have also been reported by various workers (Veeramani et al,. 2008; Anees et al., 2010; Sreenivas et al., 2012; Quadri et al., 2013).

The environmental correlations between these traits in all the generations were negative indicating that birds maturing later due to environmental factors produce larger eggs when compared to birds that mature earlier. Brah et al. (2002) also indicated that body weight during growing and laying period bears a direct influence on production and viability.

\section{Growth traits $\times$ egg weight and egg production}

The genetic correlations between growth traits and egg weight at different ages were positive in direction and moderate to high in magnitude suggesting improvement in egg weight can be achieved if selected for body weight as a correlated response.

The genetic correlation of growth traits with 28,40 , and 64 weeks egg weight was mostly positive and reports of Barot et al. (2008); Chatterjee et al. (2008a); Jayalaxmi (2008); Veeramani et al. (2008); Anees et al. (2010); Quadri et al. (2013) and Sreenivas et al. (2012) supported findings. It was found that the growth traits were negatively associated with EP40 and EP 64 weeks. The observations were similar to findings of other researchers (Ferdoci et al., 1992; Devi et al,. 2002; Jayalaxmi, 2008; Veeramani et al., 2008; Anees et al., 2010; Sreenivas et al., 2012). 


\section{Egg weight with other traits}

Egg weights at different ages (28, 40, and 64 weeks) showed positive correlations among them which are in agreement with the reports of Chatterjee et al. (2008a); Jayalaxmi (2008); Anees et al. (2010); Sreenivas et al. (2012) and Quadri et al. (2013). The high positive genetic correlation in the present study could be due to the pleotrophic genes affecting egg weight at various ages. Thus, the results indicated that egg weight at any age may be included theoretically in selection criteria to improve egg weight over the entire production periods.

\section{Egg weight $x$ egg production}

The egg weight and egg number has shown negative genetic association in all generations. Sethi et al. (2003); Vasu et al. (2004a); Chatterjee et al. (2008a) and Jayalaxmi (2008) have observed similar findings. From the study, it may be inferred that egg weight is likely to be reduced by an increase in EP40.

\section{Egg production with other traits}

The genetic correlation of EP40 with EP64 was positive and high in general Veeramani et al. (2008) and Sreenivas et al. (2012) have observed similar findings. This indicated that birds producing more number of eggs during part period continued to be good producers and had higher annual egg production. Therefore, selection based on early part period egg production can be practiced to improve the annual egg production.

\section{ACKNOWLEDGEMENTS}

I would like to thank the management and staff members of AICRP on poultry, Hyderabad for their cooperation in carrying out the present research work.

\section{REFERENCES}

Anees, C., Veeramani, P., Narayanankutty, K., Ani, B. and Riyas, M.A. 2010. Estimation of genetic and phenotypic parameters of economic traits in White Leghorn. Indian J. Poult. Sci., 45(1): 14-17.

Brah, G.S., Chaudhary, M.L. and Sandhu, I.S. 2002. Inheritance of changes in body weights over the laying cycle and their interrelationships with economic traits in White Leghorns. Indian J. Poult. Sci., 37(3): 211-214.
Barot, V.N., Savaliya, F.P., Hirani, N.D., Patel, A.B., Vataliya, P.H., Khanna, K. and Joshi, R.S. 2008. Genetic parameters of various economic traits in different generations of synthetic White Leghorn. Indian J. Poult. Sci., 43(1): 20-24.

Chatterjee, R.N., Misra, B.S. and Singh, H.N. 2002. Time trends of genetic parameters in a White Leghorn population subjected to long term single trait selection. Indian J. Anim. Sci., 72(6): 465-468.

Ferdoci, A.M., Goswami, R.N., Das, D., Laskar, S. and Shadap, O. 1992. Genetic and phenotypic parameters for alkaline phosphates and other economic traits in White Leghorn. Indian J. Poult. Sci., 27: 224-227.

Jayalaxmi, P. 2008. Genetic analysis of various productive and immunocompotence traits in White Leghorns under long term selection. Ph.D. thesis submitted to Sri Venkateswara Veterinary University, Tirupati.

Kumar, G.G., Reddy, P.M., Gupta, B.R. and Praharaj, N.K. 2004. Relative efficiency of selection based on segments of the part record to improve annual egg production in White Leghorns. Indian J. Poult. Sci., 39(3): 224-228.

Quadri, F.S., Savaliya, F.P., Patel, A.B., Joshi, R.S., Hirani, N. D. and Patil, S.S. 2013. Genetic study on important economic traits in two strains of white leghorn chicken. Indian J. Poult. Sci., 48(2): 149-153.

Rahman, M., Roy, T.C. and Das, B. 2003. Genetic studies on some economic traits of White Leghorn chickens of Meghalaya. Indian Vet. J., 80(10): 999-1001.

Sharma, A.K. and Krishna, S.T. 1998. Genotypic and phenotypic parameters of economic traits in 'V' strain of White Leghorns under selection Indian J. Poult. Sci., 33: 198-201.

Sharma, P.K., Varma, S.K., Singh, B. and Varma, R. 1999. Genetic and phenotypic effects of full sib mating on growth and production traits in White Leghorn populations. Indian J. Poult. Sci., 34: 80-82.

Sharma, R.P. and Chatterjee, R.N. 2006. Research priorities in poultry genetics and breeding to 2020. In: Poultry Research Priorities to 2020. Proceedings of National Seminar (November 2-3). Central Avian Research Institute.

Singh, B.S., Chhikara, D.S., Dalal, D.S. and Malik, C.P. 2001. Estimation of genetic and phenotypic parameters of economic traits of White Leghorn Indian J. Poult. Sci., 36: 163-168.

Singh, U.B., Chhikara, B.S. and Raheja, K.L. 2002. Estimation of genetic parameters of various economic traits over different generations of selection in a closed population of White Leghorn. Indian J. Poult. Sci., 37: 135-138.

Sethi, S., Mishra, P.K., Mishra, S.C. and Dehuri, P.K. 2003. Genetic characterization of a White Leghorn population for some production traits. Indian J. Poult. Sci., 38: 277-280. 
Sharma, R.P. and Chatterjee, R.N. 2006. Research priorities in poultry genetics and breeding to 2020. In: Poultry Research Priorities to 2020. Proceedings of National Seminar (November 2-3). Central Avian Research Institute.

Sreenivas, D., Prakash, M.G., Chatterjee, R.N. and Mahender, M. 2012. Genetic analysis of productive and reproductive traits in White Leghorn chicken. Indian J. Poult. Sci., 47(3): 274-280.
Vasu, Y., Rao, G.N., Sharma, R.P., Hazary, R.C., Gupta, B.R. and Satyanarayana, A. 2004a. Inheritance of important economic traits in IWI and control strains of White Leghorn. Indian J. Poult. Sci., 39: 1-8.

Veeramani, P., Narayanankutty, K. and Churchil, R.R. 2008. Estimation of heritability and correlation of economic traits in IWP strain of White Leghorn chicken. Indian J. Anim. Res., 42(4): 257-260. 
